\title{
Uranium-induced Cytotoxicity in HEK 293T Cells is reduced by a $\beta$-glucan type Exopolysaccharide produced by Enterobacter sp. YG4
}

\author{
K. K. Nagaraj, A. B. Arun, P. D. Rekha* \\ Yenepoya Research Centre, Yenepoya University, Deralakatte - 575018, Mangalore, Karnataka, India.
}

\begin{tabular}{l}
\hline ARTICLE INFO \\
\hline Article history: \\
Received on: $17 / 02 / 2018$ \\
Accepted on: $21 / 03 / 2018$ \\
Available online: $29 / 04 / 2018$
\end{tabular}

Key words:

Uranium;

Nephrotoxicity;

Exopolysaccharide;

$\beta$-glucan.

\begin{abstract}
Uranium-induced nephrotoxicity is a major health concern and countering it is essential. In this regard; a $\beta$-glucan type exopolysaccharide produced by Enterobacter sp. YG4 was tested for its capacity to reduce the uranyl nitrateinduced cytotoxicity in Human embryonic kidney cell line (HEK 293T). This exopolysaccharide at $0.5 \mathrm{mg} / \mathrm{mL}$ concentration was able to remove $80.94 \%$ of uranyl ions from its aqueous solution. Experiments with HEK 293T cells showed that the exposure to $0.05 \mathrm{mg} / \mathrm{mL}$ uranyl nitrate resulted in $22.13 \%$ cytotoxicity and treatment with YG4 exopolysaccharide could reduce the cytotoxicity of uranyl nitrate significantly. These results highlight the potential of this exopolysaccharide in counteracting the nephrotoxic effects of uranium.
\end{abstract}

\section{INTRODUCTION}

Extensive use of heavy metals in agriculture and industrial applications has resulted in an increase of their environmental concentrations. Uranium is one such heavy metal, which is a common component of Earth's crust and its environmental concentration varies depending on the geographical features or anthropogenic activities. The kidney is the primary target organ of uranium overexposure because of its ability to filter, reabsorb and concentrate. Nephrotoxic outcomes in human populations have been reported from uranium-contaminated sites and it was observed that both glomerular and tubular functioning were affected (Kurttio et al., 2002; Magdo et al., 2007; Okaneku et al., 2015). Uranium induced nephrotoxicity has been studied extensively in both in vitro and in vivo models. These studies show that the uranium can alter cellular nutrient/ion transport, oxidantantioxidant balance and induce apoptosis thereby affecting

${ }^{*}$ Corresponding Author

P. D. Rekha, Professor and Deputy Director, Yenepoya Research Centre, Yenepoya University, Deralakatte - 575018, Mangalore, Karnataka, India.E-mail: rekhapd@,hotmail.com glomerular and tubular functioning and structural integrity (Hao et al., 2015; Vicente-Vicente et al., 2010).

The countermeasure against uranium exposure involves the intravenous infusion of sodium bicarbonate and chelation therapy. However; blood alkalization is an inevitable outcome in sodium bicarbonate infusion. Apart from this; the inherent chemical nature of these countermeasures can put an additional burden on the already affected kidneys (Bergeron et al., 2009; Durbin, 2008). In order to develop an effective and safer countermeasure against uranium-induced nephrotoxicity; we had tested a $\beta$-glucan type exopolysaccharide (EPS) produced by the bacterium Enterobacter sp. YG4 using albino Wistar rat model. This EPS was capable of reducing the uranium-induced decrease in renal functioning and histological damage (Nagaraj et al., 2016). Continuing that study; we have conducted in vitro experiments to understand the mechanisms by which this EPS protects kidneys from the toxic effects of uranium.

\section{MATERIALS AND METHODS}

\section{Extraction of EPS}

The bacterium Enterobacter sp. YG4 was cultured in Yeast Extract Mannitol (YEM) broth for $72 \mathrm{~h}$ at $32^{\circ} \mathrm{C}$ in a shaking 
incubator (120 rpm). After incubation, the culture was centrifuged at $7000 \mathrm{rpm}$ for $10 \mathrm{~min}$ and the cell-free supernatant was mixed with ice-cold ethanol (1:3) to precipitate EPS. The precipitated EPS (YG4 EPS) was collected by centrifugation (9000 rpm, 10 min), washed with distilled water, and reprecipitated with ice-cold ethanol. The EPS was dissolved in distilled water and dialyzed against distilled water for $24 \mathrm{~h}$ in a $12-\mathrm{kDa}$ cut-off dialysis membrane (HiMedia, India). The dialyzed EPS was dried and stored for further use.

\section{Removal of uranyl ions by YG4 EPS}

The YG4 EPS solution $(500 \mu \mathrm{L})$ was mixed with equal volume of uranyl nitrate solution so that the final concentration of the EPS and uranyl nitrate in the mixture was $0.5 \mathrm{mg} / \mathrm{mL}$ and 2 $\mathrm{mg} / \mathrm{mL}$ respectively. This mixture was allowed to stand at room temperature for $15 \mathrm{~min}$ and centrifuged at $15000 \mathrm{rpm}$ for $5 \mathrm{~min}$. The uranyl ion concentration in the supernatant was determined by UV spectrophotometry. The aqueous solution of uranyl ion displays UV absorption spectrum with characteristic peaks at 415 $\mathrm{nm}, 413 \mathrm{~nm}$, and $412 \mathrm{~nm}$ (Bell and Biggers, 1965). A standard curve generated using absorption at $415 \mathrm{~nm}$ was used to determine uranyl ion in the samples. Uranyl ion concentrations in the samples and blank (without EPS) were compared to determine the ability of EPS to remove the uranyl ions.

\section{In vitro experiments}

Human embryonic kidney cell line HEK 293T (obtained from National Centre for Cell Science, India) was used for the experiment. Cells were cultured in Dulbecco's Modified Eagle Medium (DMEM) supplemented with 10\% fetal bovine serum and $1 \%$ antibiotic-antimycotic solution and incubated in a humidified atmosphere with $5 \% \mathrm{CO}_{2}$ at $37^{\circ} \mathrm{C}$.

HEK $293 \mathrm{~T}$ cells were loaded in 96 well plates at 5000 cells/well density. Cells were exposed to $0.05 \mathrm{mg} / \mathrm{mL}$ uranyl nitrate dissolved in DMEM and YG4 EPS $(0.05,0.10,0.20$, and $0.40 \mathrm{mg} / \mathrm{mL}$ ) dissolved in DMEM and incubated for $24 \mathrm{~h}$. After the incubation period; cell viability was determined by methylthiazol tetrazolium (MTT) assay. Cells not exposed to uranyl nitrate or YG4 EPS were taken as control and used for comparison.

\section{RESULTS AND DISCUSSIONS}

\section{Removal of uranyl ions by YG4 EPS}

Uranium compounds dissociate into uranyl ions $\left[\left(\mathrm{UO}_{2}\right)^{2+}\right]$ in the body fluids. These ions react with biomolecules in the kidneys and lead to kidney injury. Therefore, the property of a compound to bind with and remove uranyl ions may be useful in reducing uranium-induced nephrotoxicity. In our experiments; we observed that the YG4 EPS at $0.5 \mathrm{mg} / \mathrm{mL}$ concentration could remove $80.94 \pm 1.56 \%$ uranyl ions from its aqueous solution. The interaction between EPS molecules and metal ions has been ascribed to electrostatic interactions and coordination bond formation (Gupta and Diwan, 2017; Mohite et al., 2017). This property of removing uranyl ions can play an important role in the reduction of uranium-induced nephrotoxicity by either decreasing the absorption and distribution of uranyl ions or increasing the rate of their excretion.

\section{The activity of YG4 EPS against uranyl nitrate-induced cytotoxicity in HEK $293 \mathrm{~T}$ cells}

The YG4 EPS did not exhibit cytotoxicity towards HEK $293 \mathrm{~T}$ cells at concentrations of $0.05,0.10,0.20$, and $0.40 \mathrm{mg} / \mathrm{mL}$ for $24 \mathrm{~h}$ (Figure 1).

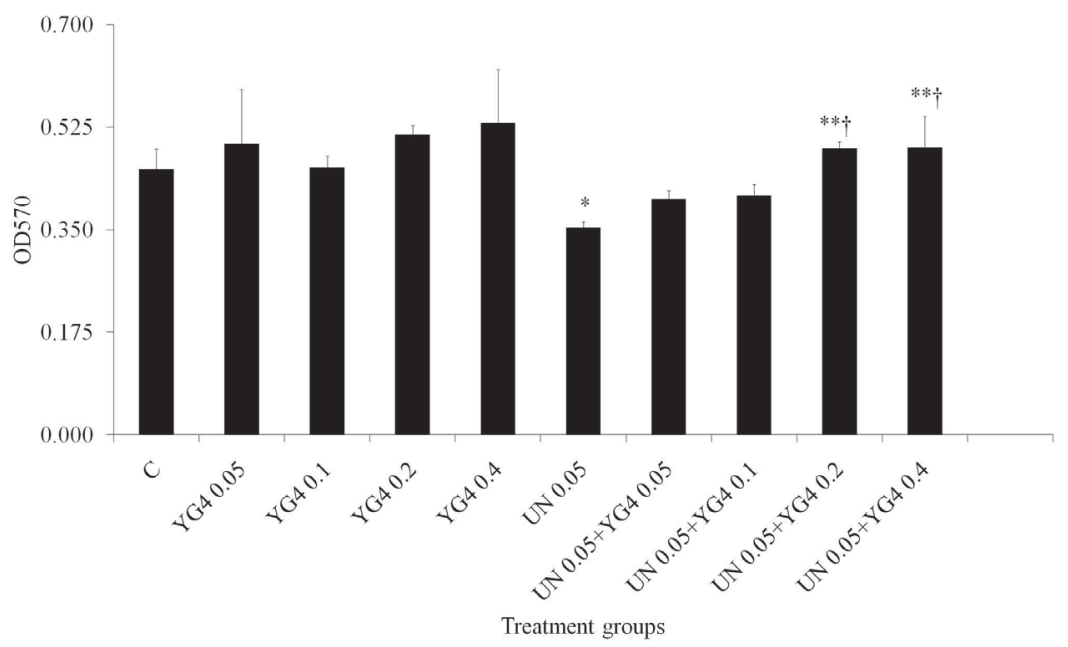

Fig. 1: The cytotoxicity of $0.05 \mathrm{mg} / \mathrm{mL}$ uranyl nitrate on HEK $293 \mathrm{~T}$ cells and activity of YG4 EPS (YG4) against it at $0.05,0.10,0.20$, and $0.40 \mathrm{mg} / \mathrm{mL}$ concentrations as determined by MTT assay. Data presented as mean $\pm \mathrm{SD}(\mathrm{n}=3)$. Bar labeled *significantly different from Control $(\mathrm{C})$ at $\mathrm{p}<0.05$ and bars labeled ** significantly different at $\mathrm{p}<0.01$ from uranyl nitrate $(\mathrm{UN})$ treatment at $0.05 \mathrm{mg} / \mathrm{mL}$.

The uranyl nitrate exposure at $0.05 \mathrm{mg} / \mathrm{mL}$ concentration for $24 \mathrm{~h}$ in HEK $293 \mathrm{~T}$ cells induced $22.13 \%$ cytotoxicity compared to control (Figure 1). Such cytotoxicity has been ascribed to uranium-induced oxidative stress or apoptosis resulting in cellular damage (Hao et al., 2012; Thiébault et al., 2007). The treatment with $\beta$-glucan type YG4 EPS completely prevented the cytotoxic effects induced by uranyl nitrate in HEK 293T cells. The treatment with YG4 EPS at 0.20 and $0.40 \mathrm{mg} / \mathrm{mL}$ concentrations against $0.05 \mathrm{mg} / \mathrm{mL}$ uranyl nitrate resulted in significant cell proliferation by $38.24 \%$ and $38.90 \%$ respectively, compared to the uranyl 
nitrate group. The treatments at 0.05 and $0.10 \mathrm{mg} / \mathrm{mL}$ also induced proliferation by $13.81 \%$ and $15.53 \%$ respectively. However; this proliferation was not statistically significant. The capacity of $\beta$-glucans to reduce cytotoxic effects under in vitro conditions has been reported earlier and such activity has been attributed to their ability to neutralize reactive oxygen species, protect cells against oxidative stress and prevent apoptotic events (Kao et al., 2012; Oliveira et al., 2007; Pourahmad et al., 2011). Our previous report (Nagaraj et al., 2016) had also shown that this $\beta$-glucan type YG4 EPS possesses antioxidant activities and is capable of reducing uranium-induced nephrotoxicity in albino Wistar rats.

\section{CONCLUSION}

The $\beta$-glucan type EPS produced by Enterobacter sp. YG4 is capable of reducing uranium-induced cytotoxicity in HEK 293 T cells. This ability can be attributed to its capacity to remove uranyl ions and its antioxidant activities. Such activities can play an important role in reducing the uranium-induced nephrotoxicity in vivo. Further experiments to comprehensively understand such activity are in progress.

\section{ACKNOWLEDGMENT}

Nagaraj KK acknowledges the support from the Board of Research in Nuclear Sciences, India (Project No: 2010/36/69BRNS).

\section{CONFLICT OF INTERESTS}

There are no conflicts of interest.

\section{REFERENCES}

Bell JT, Biggers RE. The absorption spectrum of the uranyl ion in perchlorate media: Part I. Mathematical resolution of the overlapping band structure and studies of the environmental effects. J Mol Spectrosc, $1965 ; 18: 247-275$.

Bergeron RJ, Wiegand J, Singh S. Desferrithiocin analogue uranium decorporation agents. Int J Radiat Biol, 2009; 85:348-361.

Durbin PW. Lauriston S. Taylor Lecture: the quest for therapeutic actinide chelators. Health Phys, 2008; 95:465-492.

Gupta P, Diwan B. Bacterial Exopolysaccharide mediated heavy metal removal: A review on biosynthesis, mechanism and remediation strategies. Biotechnol Rep, 2017; 13:58-71.

Hao Y, Ren J, Liu J, Luo S, Ma T, Li R, Su Y. The protective role of zinc against acute toxicity of depleted uranium in rats. Basic Clin
Pharmacol Toxicol, 2012; 111:402-410.

Hao Y, Huang J, Gu Y, Liu C, Li H, Liu J, Ren J, Yang Z, Peng S, Wang W, Li R. Metallothionein deficiency aggravates depleted uraniuminduced nephrotoxicity. Toxicol Appl Pharmacol, 2015; 287:306-315.

Kao PF, Wang SH, Hung WT, Liao YH, Lin CM, Yang WB. Structural characterization and antioxidative activity of low-molecularweights beta-1,3-glucan from the residue of extracted Ganoderma lucidum fruiting bodies. Biomed Res Int, 2011; 6:2012.

Kurttio P, Auvinen A, Salonen L, Saha H, Pekkanen J, Mäkeläinen I, Väisänen SB, Penttilä IM, Komulainen H. Renal effects of uranium in drinking water. Environ Health Perspect, 2002; 110:337.

Magdo HS, Forman J, Graber N, Newman B, Klein K, Satlin L, Amler RW, Winston JA, Landrigan PJ. Grand rounds: nephrotoxicity in a young child exposed to uranium from contaminated well water. Environ Health Perspect, 2007; 115:1237.

Mohite BV, Koli SH, Narkhede CP, Patil SN, Patil SV. Prospective of microbial exopolysaccharide for heavy metal exclusion. Appl Biochem Biotechnol, 2017; 183:582-600.

Nagaraj K, Devasya RP, Bhagwath AA. Exopolysaccharide produced by Enterobacter sp. YG4 reduces uranium induced nephrotoxicity. Int J Biol Macromol, 2016; 82:557-561.

Okaneku J, Vearrier D, Mckeever R, Lasala G, Greenberg MI. Urine uranium concentrations and renal function in residents of the United States-2001 to 2010. Clin Toxicol, 2015; 53:931-934.

Oliveira RJ, Matuo R, Da Silva AF, Matiazi HJ, Mantovani MS, Ribeiro LR. Protective effect of $\beta$-glucan extracted from Saccharomyces cerevisiae, against DNA damage and cytotoxicity in wild-type (k1) and repair-deficient (xrs5) CHO cells. Toxicol In Vitro, 2007; 21:41-52.

Pourahmad J, Shaki F, Tanbakosazan F, Ghalandari R, Ettehadi HA, Dahaghin E. Protective effects of fungal $\beta$ - $(1 \rightarrow 3)$-D-glucan against oxidative stress cytotoxicity induced by depleted uranium in isolated rat hepatocytes. Hum Exp Toxicol, 2011; 30:173-181.

Thiébault C, Carriere M, Milgram S, Simon A, Avoscan L, Gouget B. Uranium induces apoptosis and is genotoxic to normal rat kidney (NRK-52E) proximal cells. Toxicol Sci, 2007; 98:479-487.

Vicente-Vicente L, Quiros Y, Pérez-Barriocanal F, LópezNovoa JM, López-Hernández FJ, Morales AI. Nephrotoxicity of uranium: pathophysiological, diagnostic and therapeutic perspectives. Toxicol Sci, $2010 ; 118: 324-347$.

How to cite this article:

Nagaraj KK, Arun AB, Rekha PD. Uranium-induced Cytotoxicity in HEK 293T Cells is reduced by a $\beta$-glucan type Exopolysaccharide produced by Enterobacter sp. YG4. J App Pharm Sci, 2018; 8(04): 171-173. 